\title{
PERAN PEMIMPIN PEMBELAJARAN DALAM MENINGKATKAN HASIL BELAJAR SISWA
}

\author{
Ahmad Wahyudi, Bambang Sumardjoko, dan Darsinah
}

\author{
Jl. A. Yani, Tromol Pos 1, Pabelan, Kartasura, Surakarta 57102 \\ Telp. +628122685062
}

Email: wahyudiahmad96@yahoo.com,bs131@ums.ac.id\&mar243@ums.ac.id

\begin{abstract}
The purpose of this study is to describe the role of learning leadership and the obstacles faced by school principals in improving student learning outcomes at SMK Pelita Bangsa Sumberlawang Sragen. This research is a qualitative research that produces descriptive data in the form of words, written or oral from people and observed behavior. Data collection techniques carried out by in-depth interviews, observation, and documentation. Data analysis techniques using an interactive model of analysis. The results showed, first, the principal was the most instrumental element in improving the quality of education and learning. Learning leadership at SMK Pelita Bangsa Sumberlawang Sragen is carried out in 3 dimensions, namely through the formulation of school missions, good learning management, and building a conducive school climate. Second, the obstacles in implementing leadership learning in SMK Pelita Bangsa Sumberlawang Sragen include several things, namely the lack of professional teachers, conventional curriculum, incomplete supervision, and incomplete learning infrastructure.
\end{abstract}

Keywords: leadership; learning; school principal

\begin{abstract}
Abstrak. Tujuan penelitian adalah mendeskripsikan peran kepemimpinan pembelajaran dan kendala yang dihadapi kepala sekolah dalam meningkatkan hasil belajar siswa di SMK Pelita Bangsa Sumberlawang Sragen. Penelitian ini merupakan penelitian kualitatif yang menghasilkan data deskriptif berupa kata-kata, tertulis atau lisan dari orang-orang dan perilaku yang diamati. Teknik pengumpulan data dilakukan dengan wawancara mendalam, observasi, dan dokumentasi. Teknik analisis data menggunakan model interaktif analisis. Hasil penelitian menunjukkan, pertama, kepala sekolah merupakan unsur yang paling berperan dalam meningkatkan kualitas pendidikan dan pembelajaran. Kepemimpinan pembelajaran di SMK Pelita Bangsa Sumberlawang Sragen dilaksanakan dengan 3 dimensi, yaitu melalui perumusan misi sekolah, pengelolaan pembelajaran yang baik, dan membangun iklim sekolah yang kondusif. Kedua, kendala dalam pelaksanaan kepemimpinan pembelajaran di SMK Pelita Bangsa Sumberlawang Sragen meliputi beberapa hal, yaitu guru kurang profesional, kurikulum yang konvensional, supervisi yang belum menyeluruh, dan sarana prasarana pembelajaran yang belum lengkap.
\end{abstract}

Kata kunci: kepemimpinan; pembelajaran; kepala sekolah

\section{Pendahuluan}

Pendidikan merupakan bagian penting dari proses pembangunan nasional yang ikut menentukan pertumbuhan ekonomi suatu negara. Pendidikan merupakan investasi dalam pengembangan sumber daya manusia.
Peningkatan dan pengembangan sumber daya manusia secara berkelanjutan merupakan salah satu kebijakan dalam meningkatkan mutu pendidikan. Salah satu isu penting dalam penyelenggaraan pendidikan di Indonesia adalah mencari suatu cara untuk meningkatkan 
mutu pendidikan di tengah perubahan zaman yang bergerak sangat cepat. Programme for International Study Assessment (PISA) pada tahun 2015 menempatkan Indonesia sebagai salah satu Negara dengan peringkat terendah dalam pencapaian mutu pendidikan. Dari 72 negara yang dilakukan penilaian, untuk kemampuan bidang matematika, Indonesia menempati peringkat 65 dari 72 negara, bidang science menempati peringkat 63 dari 72 negara, bidang membaca menempati nomor 66 dari 72 negara. Hal ini dapat dilihat dari peringkat skor yang dicapai pada kemampuan membaca, matematika, dan sains pada pelajar yang berusia 15 tahun.

Salah satu komponen yang menentukan dalam proses pembelajaran di sekolah adalah guru. Menurut Undang-Undang nomor 14 tahun 2005 tentang guru dan dosen, pasal 1 menyatakan bahwa guru adalah pendidik profesional dengan tugas utama mendidik, mengajar, membimbing, mengarahkan, melatih, menilai, dan mengevaluasi peserta didik pada pendidikan anak usia dini jalur pendidikan formal, pendidikan dasar, dan pendidikan menengah. Ini berarti, guru mempunyai kedudukan dan peran penting dan strategis dalam rangka membentuk kepribadian bangsa melalui pengembangan potensi peserta didik dan nilai-nilai yang diinginkan. Salah satu tugas yang harus dilaksanakan guru di sekolah adalah memberikan pelayanan kepada para siswa agar mereka menjadi siswa yang selaras dengan tujuan sekolah. Selain guru sebagai pelaksana pembelajaran di dalam kelas, kepala sekolah juga memegang peran penting terhadap keberhasilan pembelajaran pendidikan di sekolah.

Priansa (2014:49) mengemukakan bahwa kepala sekolah sebagai tenaga fungsional guru yang diberi tugas untuk memimpin sekolah tempat diselenggarakannya proses belajar mengajar atau tempat di mana terjadinya interaksi antara guru yang memberikan pelajaran dan peserta didik yang menerima pelajaran.Tugas kepala sekolah salah satunya adalah memimpin pembelajaran atau instructional leadership. Kepemimpinan pembelajaran menurut Bush dan Glover (2013) adalah kepemimpinan yang menekankan pada komponen-komponen yang terkait erat dengan pembelajaran, meliputi kurikulum, proses belajar mengajar, penilaian, pengembangan guru, layanan prima dalam pembelajaran, dan pembangunan komunitas belajar di sekolah. Tujuan utama kepemimpinan pembelajaran adalah memberikan layanan prima kepada semua siswa agar mereka mampu mengembangkan potensi, bakat, minat dan kebutuhan siswa. Selain itu kepemimpinan pembelajaran juga memfasilitasi pembelajaran agar prestasi belajar siswa meningkat, kepuasan belajar semakin tinggi, motivasi belajar semakin tinggi, keingintahuan terwujudkan, kreativitas terpenuhi, inovasi terealisir, jiwa kewirausahaan terbentuk, dan kesadaran untuk belajar sepanjang hayat berkembang pesat dan tumbuh dengan baik.

Dalam pada itu ditemukan data yang sangat mengejutkan seperti dilansir Harian Kompas (17Oktober 2016), yang menyebutkan hampir setiap tahun, lebih dari satu juta lulusan sekolah menengah kejuruan menganggur. Bahkan, selama dua tahun terakhir, tingkat pengangguran di kalangan lulusan SMK paling tinggi dibandingkan dengan lulusan dari sejumlah jenjang pendidikan lain. Mengutip data yang dikeluarkan Badan Pusat Statistik (Februari 20140, tingkat pengangguran lulusan SMK sebanyak 7,21 persen, sementara lulusan SMA 9,10 persen. Namun pada Februari 2015, tingkat pengangguran dari lulusan SMK naik hingga 9,05 persen dan Februari 2016 bertambah lagi menjadi 9,84 persen alias 1,35 juta orang. Sementara tingkat pengangguran dari kalangan lulusan SMA turun menjadi 6,96 persen (http://print.kompas.com, 17/10/2016).

Berdasarkan data atas maka patut diduga bahwa praktik penyelenggaraan pendidikan selama ini terdapat sejumlah persoalan, terutama yang berkaitan dengan aspek mutu pendidikan. Persoalan yang terjadi ini diduga karena rendahnya kualitas lulusan dari SMK sehingga tidak memenuhi kualifikasi yang di persyaratkan memasuki dunia kerja. Rendahnya kualitas lulusan 
dari SMK tentu saja bukan hanya tanggung jawab guru melainkan menjadi tanggung jawab Kepala Sekolah. Sebagai pimpinan di sekolah, Kepala sekolah dalam pengelolaan pendidikan memiliki peran dan tugas yang sering dikenal dengan EMASLIM (Educator, Manager, Administrator, Supervisor, Leader, Inovator, dan Motivator). Salah satu peran yang harus dilaksanakan kepala sekolah yaitu sebagai pemimpin (leader). Untuk dapat meningkatkan kualitas pendidikan di sekolah kepala sekolah berperan sebagai pemimpin pembelajaran sebagaimana mestinya.

SMK Pelita Bangsa sebagai salah satu SMK di Kecamatan Sumberlawang Sragen, yang berdiri tahun 2011 sampai dengan tahun 2018 sudah meluluskan sebanyak 5 kali dengan rata-rata lulusan pertahun sebanyak 100 orang. Dengan demikian maka jumlah alumninya telah mencapai 500 siswa. Berdasarkan data penelusuran alumni di SMK Pelita Bangsa Sumberlawang di peroleh informasi bahwa yang sudah terserap ke dalam dunia kerja belum mencapai $50 \%$. Hal ini memunculkan sebuah pertanyaan bahwa apa yang membuat alumni SMK Pelita Bangsa Sumberlawang sulit terserap ke dunia kerja? Kemudian, bagaimana peran kepala sekolah sebagai pemimpin pembelajaran dalam meningkatkan hasil belajar siswa di SMK Pelita Bangsa Sumberlawang Sragen?

Berdasarkan uraian di atas maka fokus penelitian ini mengarah pada peran kepala sekolah sebagai pemimpin pembelajaran dalam meningkatkan hasil belajar siswa di SMK Pelita Bangsa Sumberlawang Sragen. Selanjutnya, tujuan penelitian ini adalah mendeskripsikan pelaksanaan kepemimpinan pembelajaran dan kendala yang dihadapi kepala sekolah dalam meningkatkan hasil belajar siswa di SMK Pelita Bangsa Sumberlawang Sragen.

\section{Metode Penelitian}

Penelitian ini merupakan penelitian kualitatif deskriptif yang menghasilkan data deskriptif berupa kata-kata tertulis atau lisan dari orang-orang dan perilaku yang dapat diamati. Karena itu data penelitian yang digali adalah data pelaksanaan kepemimpinan pembelajaran oleh kepala sekolah dan kendala dalam melaksanakan kepemimpinan pembelajaran. Penelitian dilakukan di SMK Pelita Bangsa Sumberlawang, yang terletak di jalan Proyek Kedungombo km.1, Ngandul, Sumberlawang, Kabupaten Sragen. Waktu penelitian dimulai bulan Januari dan berakhir bulan Juni 2019. Teknik pengumpulan data menggunakan wawancara mendalam, observasi, dan dokumentasi. Karena itu, sumber data penelitian ini adalah kepala sekolah, wakil kepala sekolah, guru, siswa, dan pengurus yayasan SMK Pelita Bangsa Sumberlawang. Teknik analisis data yang digunakan model analisis interaktif dengan langkah-langkah analisis yang meliputi reduksi data, penyajian data, dan penarikan simpulan.

\section{Hasil dan Pembahasan \\ Pelaksanaan Kepemimpinan Pembelajaran}

Hasil penelitian menunjukkan bahwa kepemimpinan pembelajaran kepala sekolah SMK Pelita Bangsa Sumberlawang memiliki peran yang sangat penting dalam meningkatkan kualitas pendidikan di sekolah. Sebagai sekolah swasta, Kepala Sekolah mempunyai tanggung jawab besar dalam mengelola manajemen sekolah yang terkait langsung dengan proses pembelajaran. Temuan ini sesuai dengan pendapat Mulyasa (2013:24) yang menyatakan bahwa kepala sekolah adalah komponen yang paling berperan dalam meningkatkan kualitas pendidikan. Begitu pula Ermita (2010) yang menyatakan bahwa kepala sekolah adalah salah satu komponen yang ikut berperan dalam pengelolaan lembaga pendidikan.

Pelaksanaan

kepemimpinan pembelajaran kepala sekolah SMK Pelita Bangsa Sumberlawang untuk meningkatkan hasil belajar siswa dapat dilihat dari berbagai kebijakan yang diambil. Berdasarkan model kepemimpinan pembelajaran Hallinger dan Murphy (1985), kepala sekolah telah melaksanakan praktik kepemimpinan 
pembelajaran yang meliputi 3 dimensi dan 11 deskriptor kebijakan. Ketiga dimensi itu meliputi merumuskan misi, mengelola program pembelajaran, dan membangun iklim kademik.

Dimensi pertama, merumuskan misi. Pada dimensi ini terdapat 2 deskriptor, yaitu merumuskan dan mengkomunikasikan tujuan sekolah. Deskriptor pertama, menunjukkan bahwa visi, misi, dan tujuan SMK Pelita Bangsa Sumberlawang ditetapkan oleh Yayasan Pelita Bangsa. Kepala sekolah dan seluruh warga sekolah sebagai pelaksana. Oleh karena itu kepala sekolah diharapkan mampu merumuskan program kerja bersama dengan warga sekolah untuk mencapai tujuan sekolah.

"Visi, misi, dan tujuan SMK Pelita Bangsa Sumberlawang dirumuskan dan disahkan oleh Yayasan Pelita Bangsa Sumberlawang. Sejak berdiri tahun 2011 visi, misi, dan tujuan sekolah belum pernah dievaluasi dan diubah. Sekolah melalui kepala sekolah hanya melaksanakan apa yang sudah menjadi keputusan dari Yayasan" (WKS, 20-0419).

Setelah program kerja disusun langkah kedua, adalah mengkomunikasikan dengan seluruh warga sekolah dan stakeholder.

"Visi, misi, dan tujuan SMK Pelita Bangsa Sumberlawang dilakukan oleh pihak Yayasan Pelita Bangsa Sumberlawang. Melalui bapak kepala sekolah visi, misi, dan tujuan sekolah disampaikan kepada seluruh warga sekolah dengan membuat tulisan, yang berisi visi, misi, dan tujuan sekolah yang ditempel di setiap sudut sekolah maupun dijelaskan pada saat rapat dewan guru. Untuk dapat mencapai tujuan sekolah, kepala sekolah menyusun langkah-langkah strategis bersama dengan komponen sekolah dan stakeholder yang ada sehingga keputusan yang diambil adalah hasil kesepakatan bersama, bukan keputusan sepihak dari kepala sekolah" (WG-Ing, 22-04-19)

Seluruh program yang disusun kepala sekolah berorientasi pada peningkatan hasil belajar siswa agar dapat meningkatkan kualitas pendidikan di sekolah dan pencapaian tujuan sekolah. Temuan ini sesuai dengan penelitian tentang kemampuan kepala sekolah terkait kompetensi administrasi yang dilakukan oleh Adegbemile yang berjudul Principal's Competency Needs For Effective Schools Administration In Nigeria di tingkat sekolah menengah di South Geo Barat, Nigeria. Hasil penelitian menunjukkam bahwa keterampilan kepemimpinan instruksional yang dibutuhkan oleh kepala sekolah untuk administrasi sekolah yang efektif mencakup adanya: (1) kepala sekolah bekerjasama dengan guru untuk menentukan tujuan Sekolah, (2) penyediaan fasilitas, (3) mengawasi rencana pelajaran, (4) kegiatan belajar mengajar, dan (5) evaluasi rencana dan pelaksanaan kurikulum.

Penelitian lain dilaksanakan oleh Prytula, Noonan, dan Hellsten yang berjudul "Toward Instructional Leadership: Principals' Perceptions of Large Scale Assessment in Schools". Penelitian ini mengkaji tentang persepsi kepala sekolah terhadap reformasi pengukuran kinerja kepala sekolah dan bagaimana pengukuran tersebut mempengaruhi peran mereka sebagai kepala sekolah. Hasil penelitian menunjukkan bahwa reformasi pengukuran kinerja kepala sekolah berpengaruh positif terhadap kepemimpinan pembelajaran yang mencakup penetapan tujuan sekolah, peningkatan pelaksanaan pembelajaran, dan perubahan pengukuran terhadap pembelajaran siswa.

Dimensi kedua, mengelola program pembelajaran. Pada dimensi ini terdapat tiga deskriptor, yaitu melakukan supervisi dan evaluasi pembelajaran, koordinasi kurikulum, dan memonitor kemajuan pembelajaran siswa. Deskriptor pertama, dalam praktik kualitas pendidikan di sekolah sangat tergantung dari proses belajar mengajar di sekolah. Karena itu kepala sekolah dalam perannya sebagai 
pemimpin pembelajaran perlu melakukan supervisi dan evaluasi pembelajaran. Kepala SMK Pelita Bangsa Sumberlawang telah melaksanakan supervisi pembelajaran secara periodik pada semua guru setiap satu tahun sekali pada awal tahun pelajaran.

"Bapak kepala sekolah selalu memperhatikan proses pembelajaran yang ada di kelas, hampir setiap pagi di mana jam pelejaran sudah dimulai bapak kepala sekolah selalu muter ke tiap-tiap kelas untuk memastikan bapak ibu guru yang ada jam mengajar melaksanakan tugasnya. Apabila ada jam mengajar tapi bapak ibu guru tidak masuk ke dalam kelas, maka bapak kepala biasanya masuk dan mengisi kelas yang kosong. Selanjutnya bapak kepala sekolah akan memanggil bapak ibu guru yang bersangkutan untuk diberikan pembinaan. Bapak kepala sekolah juga melaksanakan supervisi kelas secara periodik dan terjadwal setiap satu tahun sekali untuk mengetahui bagaimana bapak ibu guru mengajar di dalam kelas. Selanjutnya bapak kepala sekolah akan memberikan pembinaan dan melaksanakan tindak lanjutnya." (WG-IPS, 22-04-19)

Data di atas menunjukkan bahwa kepala sekolah telah berupaya untuk membantu dan mengembangkan profesionalitas guru dengan berorientasi pada teknik individu, kelompok, kunjungan kelas. Supervisi yang dilakukan bertujuan untuk meningkatkan proses kegiatan pembelajaran sehingga seluruh aktivitas organisasi bermuara pada pencapaian efisiensi dan efektivitas pembelajaran. Namun, pelaksanaan supervisi di SMK Pelita Bangsa Sumberlawang belum dilakukan secara menyeluruh. Hal ini karena tahap pertemuan balikan/ tindak lanjut belum dilaksanakan oleh guru maupun kepala sekolah. Hal inilah yang mengakibatkan palaksanaan supervisi hanya barsifat formalitas sekedar memenuhi kewajiban.

Temuan di atas sesuai dengan penelitian
Kotirde \& Yunos (2014) dengan judul "The Processes of Supervision in Seconday Schools Educational System in Nigeria" bahwa proses supervisi sekolah menengah di Nigeria mencakup dua tahap, yakni supervisi kepala sekolah dan guru. Setiap tahap berfokus pada pencapian hasil supervisi masingmasing tahap. Output dari supervisi kepala sekolah adalah pada pencapaian frekuensi dan efektifitas dari aturan, nilai, karakter dan persaingan gender di sekolah. Output dari supervisi guru adalah eksplorasi peran guru, partisipasi siswa, motivasi, dan evaluasi pembelajaran.

Sidhu, G Kaur dan Fook, Chan Yuen (2010) dalam penelitiannya yang berjudul "Formative Supervision of Teaching and Learning: Issues and Concerns for the School Head" menjelaskan tentang peran kepala sekolah sebagai supervisor adalah untuk meningkatkan kualitas guru. Penelitian ini menyoroti mengenai pengetahuan, pemahaman, dan praktek kepala sekolah dasar sebagai pengawas formatif. Penelitian lain dilakukan Suryantini, berjudul peningkatan kompetensi supervisi kepala sekolah melalui supervisi kelompok di sekolah dasar tentang kemampuan supervisi dengan fokus pada proses pelaksanaan supervisi kelompok guna meningkatkan kompetensi supervisi bagi kepala sekolah. Berdasarkan penelitian tersebut disimpulkan bahwa: (1) proses pelaksanaan supervisi manajerial dilakukan melalui prosedur berbentuk siklus, yang terdiri atas tiga tahapan, yaitu pendahuluan, pengamatan, dan balikan. (2) penerapan supervisi manajerial metode kelompok efektif dalam meningkatkan kompetensi supervisi kepala sekolah. Hal ini ditunjukkan dengan hasil penilaian yang mengalami peningkatan pada setiap siklus tindakan yang dilakukan.

Deskriptor kedua, adalah mengkoordinasikan kurikulum. Kurikulum merupakanpanduanyangdijadikangurusebagai kerangka acuan untuk mengembangkan proses pembelajaran. Seluruh aktivitas pembelajaran, mulai dari penyusunan rencana pembelajaran, pemilihan materi pembelajaran, menentukan 
pendekatan dan strategi atau metode, memilih dan menentukan media pembelajaran, dan menentukan teknik evaluasi berpedoman pada kurikulum yang berlaku. Kurikulum disusun berdasarkan tuntutan perubahan jaman dan kemajuan masyarakat, sehingga kurikulum harus terus mengalami perubahan. Perubahan kurikulum adalah suatu keniscayaan, apabila kurikulum tidak mengalami penyesuaian dan perubahan sementara kehidupan sosial, teknologi dan dimensi-dimensi kehidupan lainnya maka dipastikan kurikulum tidak mampu memenuhi tuntutan perubahan.

Hasil penelitian di SMK Pelita Bangsa Sumberlawang menunjukan bahwa dalam pembuatan kurikulum yang diterapkan bersifat statis dan kurang dapat mengikuti perubahan perkembangan jaman. Akibatnya output sekolah kurang dapat mengikuti kebutuhan pasar tenaga kerja yang ada di dunia industri. Hal inilah yang menyebabkan banyaknya lulusan SMK Pelita Bangsa yang tidak terserap di dunia kerja sesuai dengan bidang keahlian yang dipelajari di sekolah.

Deskriptor ketiga, yaitu memonitor kemajuan pembelajaran siswa. Monitoring adalah kegiatan yang dilaksanakan oleh kepala sekolah dalam rangka memantau kinerja guru. Pelaksanaan kegiatan monitoring yang dilakukan kepala sekolah yaitu dengan berjalan berkeliling di setiap teras kelas untuk memastikan terlaksananya kegiatan belajar mengajar sesuai jadwal. Tidak jarang bapak kepala sekolah mengisi kelas bagi bapak ibu guru yang belum hadir. Kegiatan monitoring dilaksanakan secara rutin setiap pagi di sekolah agar proses pembelajaran dapat terlaksana dengan efektif dan efisien.

Pelaksanaan pemantauan di sekolah juga dilakukan dengan mengumpulkan jurnal harian yang ada di kelas oleh wali kelas setiap minggu sekali. Selanjutnya jurnal harian kelas direkap sebagai bahan laporan kepada kepala sekolah untuk dapat dilakukan tindak lanjut. Pengumpulan jurnal harian kelas adalah untuk mengetahui kedisiplinan guru dalam melaksanakan tugas mengajar, juga sebagai laporan proses kemajuan pembelajaran siswa.
Dengan demikian maka kepala sekolah dapat mengetahui perkembangan pembelajaran siswa yang berada di dalam kelas, sehingga apabila terjadi permasalahan pembelajaran di dalam kelas segera diketahui dan terselesaikan oleh kepala sekolah.

Dimensi ketiga, membangun iklim sekolah. Pada dimensi ini terdiri dari enam deskriptor, yaitu mengkontrol alokasi waktu pembelajaran, mendorong pengembangan profesi, memfokuskan pencapaian visi, menyediakan insentif bagi guru, menetapkan standar akademik, dan menyediakan insentif bagi siswa. Hasil penelitian menunjukkan bahwa di SMK Pelita Bangsa Sumberlawang enam deskriptor di atas menjadikan iklim sekolah kondusif. Dengan iklim sekolah yang aman, nyaman, dan menyenangkan (kondusif) mengakibatkan siswa lebih fokus dalam belajar.

Hasil penelitian di atas didukung penelitian Johnson, Uline, dan Perez (2011) dengan judul "Expert Noticing and Principals of High-Performing Urban Schools". Penelitian ini bertujuan untuk mengkaji peranan kepemimpinan pembelajaran kepala sekolah dalam menunjang kemajuan sekolah di wilayah urban di Amerika Serikat. Hasil penelitian menunjukkan bahwa kepala sekolah memberikan perhatian yang tinggi terhadap hal-hal yang berkaitan dengan keterlibatan siswa dalam pembelajaran dan penciptaan iklim atau suasana di ruangan kelas. Kepala sekolah sangat memperhatikan tentang bagaimana guru dalam menciptakan suasana pembelajaran di kelas agar selalu kondusif.

Berdasarkan uraian di atas disimpulkan bahwa untuk dapat melaksanakan proses pembelajaran yang efektif diperlukan iklim sekolah yang kondusif. Untuk dapat membangun iklim sekolah yang kondusif dapat dimulai dengan pengaturan waktu belajar siswa dalam setiap harinya, meningkatkan kompetensi atau profesionalitas guru dan penetapan standar akademik staf pengajar sesuai peraturan perundang-undangan yang ada. Hal lain yang dapat dilakukan adalah fokus dalam pencapaian visi sekolah, 
pemberian apresiasi berupa insentif bagi guru dan siswa yang berprestasi.

\section{Kendala Praktik Kepemimpinan Pembelajaran}

Berdasarkan penelitian di SMK Pelita Bangsa Sumberlawang, diperoleh hasil bahwa pelaksanaan kepemimpinan pembelajaran masih mengalami kendala, terutama yang berasal dari lingkungan sekolah. Pertama, dari segi Guru. Dalam melaksanakan peran kepala sekolah sebagai pemimpin pembelajaran, guru merupakan jantung pendidikan. Untuk menghasilkan pendidikan yang baik diperlukan guru yang berkualitas, yang memiliki kompetensi dan memiliki profesionalitas yang tinggi. Tugas guru yaitu menyampaikan pengetahuan dan ketrampilan, serta mengembangkan sikap peserta didik. Oleh karena itu guru harus mampu menguasai bahan atau materi yang diajarkan, mampu menyampaikan materi ajar kepada para siswa agar tujuan pembelajaran yang diinginkan dapat tercapai. Namun kenyataannya belum semua guru mampu berbuat profesional, guru hanya sekedar melaksanakan tugas tanpa memperhatikan hasil belajar siswa. Hal ini terjadi karena kurangnya kompetensi yang dimiliki oleh seorang guru.

Abdul Hadis (2010) menyampaikan bahwaguru sebagaipendidikmerupakantenaga profesional yang bertugas merencanakan dan melaksanakan proses pembelajaran, menilai hasil pembelajaran, melakukan bimbingan dan pelatihan, serta melakukan penelitian dan pengabdian kepada masyarakat, terutama bagi para pendidik di jenjang pendidikan tinggi sehingga dapat dikatakan bahwa guru adalah penentu keberhasilan pendidikan dalam sebuah sekolah. Pendapat dari Abdul Hadis (2010) ditegaskan lagi dalam Permendikbud no 22 tahun 2016 yang menyatakan bahwa pelaksanaan pembelajaran merupakan implementasi dari RPP, meliputi kegiatan pendahuluan, inti, dan penutup.

Berdasarkan penelitian, di SMK Pelita Bangsa Sumberlawang masih ada guru yang belum memiliki ijasah sampai sarjana tetapi mengajar. Selain itu berdasarkan data yang ada ditemukan bahwa ada beberapa guru yang mengajar tidak pada kompetensi yang sesuai dengan disiplin ilmu yang dimiliki. Guru hanya sekedar melaksanakan tugas tanpa memperhatikan tugas utama. Dengan demikian harapan kepala sekolah untuk meningkatkan prestasi siswa sulit dicapai.

Selain guru yang belum memiliki kualifikasi pendidikan sampai sarjana dan sudah mengajar, juga ditemukan banyaknya guru yang mengajar tidak sesuai dengan disiplin ilmu yang dimiliki. Berdasarkan data, dari 24 guru yang mengajar terdapat 6 guru mengajar mata pelajaran yang tidak linier dengan pendidikannya. Dengan demikian terdapat 25\% guru tidak profesional di SMK Pelita Bangsa Sumberlawang. Dilihat dari kepemilikan sertifikat pendidik guru, dari total guru SMK Pelita Bangsa Sumberlawang, hanya 4 guru yang memiliki sertifikat pendidik atau sertifikat kompetensi dari Lembaga Sertifikasi Profesi (LSP). Dengan demikian dapat dikatakan bahwa guru di SMK Pelita Bangsa Sumberlawang mayoritas belum menjadi guru yang profesional. Karena itu para guru dapat meningkatkan kompetensinya dengan mengikuti berbagai macam pelatihan, seminar, workshop, dan pendidikan profesi untuk meningkatkan kompetensi. Bagi bapak ibu guru yang sudah memenuhi persyaratan mengikuti pendidikan profesi guru dalam jabatan yang diselenggarakan oleh pemerintah juga sangat didorong oleh kepala sekolah untuk dapat mengikutinya melalui mekanisme yang sudah ada.

Kedua, dari segi kurikulum. Kurikulum merupakan panduan yang dijadikan guru sebagai kerangka acuan untuk mengembangkan proses pembelajaran. Seluruh aktivitas pembelajaran, mulai dari penyusunan rencana pembelajaran, pemilihan materi pembelajaran, menentukan pendekatan dan strategi/metode, memilih dan menentukan media pembelajaran, menentukan teknik evaluasi, kesemuanya harus berpedoman pada kurikulum. Kurikulum harus disusun berdasarkan tuntutan perubahan jaman dan 
kemajuan masyarakat. Apabila kurikulum tidak mengalami penyesuaian dan perubahan sementara kehidupan sosial, teknologi dan dimensi-dimensi kehidupan lainnya terus mengalami perubahan, maka dipastikan kurikulum tidak mampu memenuhi tuntutan perubahan. Hal itu juga berarti bahwa segala sesuatu yang diajarkan di sekolah, tidak dapat mengikuti tuntutan perubahan yang terjadi pada dunia kerja.

Hasil penelitian di SMK Pelita Bangsa Sumberlawang menunjukkan bahwa dalam pembuatan kurikulum yang diterapkan bersifat statis dan kurang dapat mengikuti perubahan perkembangan jaman. Akibatnya output atau lulusan dari sekolah kurang dapat mengikuti kebutuhan pasar tenaga kerja. Hal inilah yang menyebabkan kenapa banyak lulusan SMK Pelita Bangsa yang tidak terserap di dunia kerja sesuai dengan bidang keahlian yang dipelajari di sekolah.

Ketiga, dari segi sarana manajerial. Dalam manajemen modern seorang pemimpin berperan sebagai pengelola, yaitu berfungsi sebagai perencana, pengorganisasian, dan pengawasan. Seorang kepala sekolah diharapkan mampu menjalankan perannya sebagai manajer dan juga supervisor pengajaran serta sebagai evaluator program sekolah. Berdasarkan hasil penelitian diperoleh data bahwa pelaksanaan supervisi pembelajaran sudah dilaksanakan satu kali dalam satu tahun setiap awal tahun pelajaran. Di mulai dari tahap perencanaan dilanjutkan dengan pelaksanaan supervisi pembelajaran di dalam kelas. Namun sampai dengan saat ini hanya berhenti pada tahap pelaksanaan dan belum dilakukan tindak lanjut hasil supervisi. Hal ini mengakibatkan supervisi yang telah dilaksanakan belum memperoleh hasil sesuai dengan harapan.

Suryantini (2016) dalam penelitiannya yang berjudul Peningkatan kompetensi supervisi kepala sekolah melalui supervisi kelompok di sekolah dasarmenyampaikan tentang kemampuan supervisi dengan fokus pada proses pelaksanaan supervisi kelompok guna meningkatkan kompetensi supervisi bagi Kepala sekolah. Hasil penelitian menyimpulkan bahwa: (1) proses pelaksanaan supervisi manajerial dilakukan melalui prosedur berbentuk siklus yang terdiri dari tiga tahap yaitu: tahap pertemuan pendahuluan, tahap pengamatan dan tahap pertemuan balikan; dan (2) penerapan supervisi manajerial metode kelompok efektif dalam meningkatkan kompetensi supervisi kepala sekolah. Hal ini ditunjukkan dengan hasil penilaian yang mengalami peningkatan pada setiap siklus tindakan yang dilakukan.

Berdasarkan pendapat Suryantini (2016) tersebut jelas bahwa proses supervisi tidak hanya berhenti pada tahap pertemuan pendahuluan, dan tahap pengamatan/ pelaksanaan tetapi harus berlanjut pada tahap pertemuan balikan/ tindak lanjut. Dengan adanya pertemuan tindak lanjut maka hasil pelaksanaan supervisi dapat dinilai dengan ditunjukkan hasil penilaian yang mengalami peningkatan pada setiap siklus tindakan yang dilakukan.

Keempat, segi sarana dan prasarana. Ketersedian fasilitas kelas dan laboratorium, alat-alat praktek, buku-buku pelajaran, media pembelajaran merupakan kemponen penting yang dapat mendukung terwujudnya kegiatan belajar siswa. Ketersediaan prasarana dan sarana pembelajaran dapat memberikan kemudahan bagi guru dan siswa dalam melaksanakan kegiatan belajar mengajar. Sarana dan prasarana juga dapat mendorong terwujudnya proses pembelajaran yang efektif karena guru dapat menggunakan media pembelajaran dalam memperjelas materi pelajaran serta kelancaran kegiatan belajar. Ketersediaan prasarana dan sarana pembelajaran berdampak terhadap terciptanya iklim pembelajaran yang lebih kondusif dapat memotivasi siswa untuk mencapai hasil belajar yang lebih baik. Karena itu sarana dan prasarana menjadi bagian yang penting untuk mendukung terwujudnya proses pembelajaran yang diharapkan. Hasil penelitian menunjukkan bahwa ketersediaan fasilitas kelas dan laboratorium, alat-alat praktek, buku-buku pelajaran, media pembelajaran 
masih sangat kurang. Media pembelajaran di dalam kelas yang berupa LCD maupun ruang praktek siswa yang tersedia kurang representative dengan jumlah siswa yang ada. Karena itu siswa kurang maksimal dalam melaksanakan praktek di dalam bengkel atau laboratorium.

\section{Simpulan}

Berdasarkan hasil penelitian dapat disimpulkan bahwa, pertama, kepala sekolah merupakan unsur yang paling berperan dalam meningkatkan kualitas pendidikan dan pembelajaran. Pelaksanaan kepemimpinan pembelajaran di SMK Pelita Bangsa Sumberlawang berjalan dengan baik. Visi, misi, dan tujuan sekolah ditetapkan oleh Yayasan, sementara kepala sekolah dan jajarannya sebagai pelaksana dengan menyusun program sekolah yang berorientasi terhadap tercapainya tujuan sekolah. Pengelolaan pembelajaran dilaksanakan dengan melakukan supervisi dan evaluasi pembelajaran, mengkoordinasikan kurikulum berdasarkan tuntutan perubahan dan kemajuan masyarakat, serta memonitor kemajuan pembelajaran siswa. Kedua, dalam melaksanakan kepemimpinan pembelajaran di SMK Pelita Bangsa Sumberlawang terdapat beberapa kendala antara lain dari segi Guru yaitu kurangnya profesionalisme guru. Dari segi kurikulum yang menjadi permasalahan adalah kurikulum yang diterapkan di SMK Pelita Bangsa Sumberlawang masih bersifat statis dan kurang dapat mengikuti perubahan perkembangan jaman. Dari segi manajerial yang menjadi permasalahan adalah pelaksanaan supervisi yang sudah berjalan baru dalam tahap perencanaan dan pelaksanaan supervisi. Dari segi sarana dan prasarana yang menjadi permasalahan adalah kurangnya media pembelajaran dan praktek siswa. Pembelajaran terkesan bersifat teoritis dan kurangnya praktek.

\section{Daftar Pustaka}

Adegbemile, Oluwadare, 2011. "Principal's Competency Needs For Effective Schools Administration In Nigeria". Journal of Education and Practice. www.iiste.org. ISSN: 2222-1735 (Paper) ISSN 2222-288X (Online) Vol 2 no 4.

Darno, 2013. "Kepemimpinan Kepala Sekolah Dalam Meningkatkan Mutu Sekolah MI Tarbiyatul Athfal 03 Pengarasan Kecamatan Bantar Kawung Kabupaten Brebes Tahun Pelajaran 2011/2012". Tesis. Semarang: Program Pasca Sarjana Universitas Negeri Semarang.

Erna Widiyanti. 2018. "Pengaruh Kepemimpinan Kepala Sekolah dan Budaya Sekolah Melalui Motivasi Terhadap Kinerja Guru Sekolah Menengah Pertama Kota Semarang”. Tesis. Semarang: Program Pasca Sarjana Universitas Negeri Semarang

https://en.wikipedia.org/wiki/Programme_for_International_Student_Assessment tahun 2015. https://tongka109.wordpress.com/2010/04/06/hambatan-perencanaan-dan-pelaksanaanpembelajaran/, diakses hari sabtu, 29 September 2018 pukul 19.30 WIB.

https://winawimala.wordpress.com/2011/03/24/faktor-penghambat-dalam-belajar-dan-caramengatasinya/, diakses hari sabtu, 29 September 2018 pukul 20.30 WIB.

http://biosbetter.blogspot.com /2016/04/ masalah - masalah - dalam - pembelajaran - di.html, diakses hari sabtu, 6 Juni 2019 pukul 21.30 WIB.

https://www.vedcmalang.com/pppptkboemlg/index.php/menuutama/departemen-bangunan30/1352-b-wijanarko, diakses hari sabtu, 8 Juni 2019 pukul 11.30 WIB.

Johnson, Joseph F., Jr., Cynthia L Uline, dan Lynne G.Perez. 2011. ”Expert Noticing and Principals of High-Performing Urban Schools". Journal for The Education of Student 
Placed at Risk Vol 1, 2011. PP: 1-33, http://www.proquest.umi.com di akses pada 12 September 2018.

Keputusan Menteri Pendidikan Nasional Nomor. 162/U/2003 tentang Pedoman Penugasan Guru sebagai Kepala Sekolah.

Kotirde, I.Y \& Yunos J.B. Md, 2014. "The Processes of Supervision in Seconday Schools Educational System in Nigeria". Procedia Sosial and Behavioral Sciences, Vol.204.2015: pp 259-264.

Mulyasa. 2013. Menjadi Kepala Sekolah Profesional. Bandung. PT. remaja Rosda karya.

Peraturan Menteri Pendidikan Dan KebudayaanNomor 22Tahun 2016 TentangStandar Proses Pendidikan Dasar Dan Menengah.

Peraturan Menteri Pendidikan Nasional No 13 Tahun 2007 Tentang Standar Kepala Sekolah/ Madrasah.

Priansa, Doni Juni, 2014, Manajemen Supervisi dan Kepemimpinan Kepala Sekolah, Bandung: Alfabeta.

Prytula, Michelle, Brian Noonan, dan Laurie Hellsten. 2013. “Toward Instructional Leadership: Principals' Perceptions of Large Scale Assessment in Schools".Canadian journal of Educational Administration and Policy, Issue \#140, March 12, 2013, pp: 1-30, http:// www.proquest.umi.com di akses pada 13 September 2018.

Sidhu, G Kaur dan Fook, Chan Yuen. 2010. "Formative Supervision of Teaching and Learning: Issues and Concerns for the School Head”. European Journal of Scientific Research. Vol. 39 No. 4. Pg:589-605.

Suryantini, 2016. "Peningkatan Kompetensi Supervisi Kepala Sekolah Melalui Supervisi Kelompok di Sekolah Dasar". Jurnal Managemen Pendidikan. ISSN: 1907-4034, Vol 11, No. 2, Januari 2016: PP 9-17.

Sutama dkk, 2017. Pedoman Penulisan Tesis. Surakarta: UMS.

Undang-Undang Nomor 14 Tahun 2005 Tentang Guru Dan Dosen. 